\title{
CLOUD COMPUTING IN HIGHER EDUCATION OF THE USA
}

In the modern world, information has acquired the importance of one of the main resources. Scientific and educational, economic and military institutions in the information society are highly dependent on information and the level of communication technology development. Cloud technologies are actively being used nowadays. The concept of cloud computing has various interpretations, but primarily refers to technology that provides powerful computing resources over the Internet. The benefits of introducing these systems are most often discussed in relation to business, but their impact on the education sector is no less significant. Educational institutions around the world have already implemented the cloud in their educational process and use its huge potential for innovation. Cloud services are an excellent alternative to traditional education, because they do not experience a large shortage of resources for functioning, and do not require large expenses for computers and other devices. For the successful implementation and use of cloud services, a large number of qualified specialists are constantly required. The results of literature review show that the United States is one of the leaders in the market of information services, and American universities occupy leading positions in world ratings for the quality of IT education. Modern American educational institutions are constantly turning to the use of cloud services and already have extensive experience in the use of cloud computing. It should be noted that domestic higher education institutions are not so actively integrating cloud technologies into the educational process in comparison with their American counterparts. With the high budget cuts for higher education at Ukrainian universities and the ever-increasing demand for information technology services, Ukrainian higher education institutions should consider adopting cloud computing strategies to meet the growing demand for IT services. In the context of state funding of Ukrainian higher education institutions and their gradual transition to self-sufficient economic existence, cloud computing can offer profitable business models for Ukrainian universities, as these universities often lack the resources and knowledge to manage the necessary IT support for educational, scientific-research and research activities that should be provided in modern higher education, while cloud computing aims to eliminate these difficulties.

Key words: cloud computing, bachelor of science, curriculum, higher education, educational technology.

Introduction. Today, in most US universities, education and information technology interact very closely. Some teaching and learning applications have become key tools in the academic environment since the introduction of Web 2.0 applications in 1999. Social networks such as Facebook, Twitter, Linkedln, and others provide new ways to teach dialogue, interaction, collaboration, and sharing. They are also an excellent additional tool for students to master complex topics, and to disseminate course ideas and study material among students. Nowadays the technologies are developing rapidly and the amount of information used in training is increasing. Therefore, the requirements for such applications are constantly growing. Hence, the idea of providing such a platform with the ability to store data of any size and type was gradually developed from 1982 to 2015 under the Cloud Computing name.

When working with a variety of documents and files, security and accessibility characteristics never lose their importance. Security is the eternal problem of the Internet and open networks, especially when considering cloud security. Insecurity is perhaps the most important flaw in cloud technology. In this context, an overview of ideas, types of cloud services, typical cloud computing applications in higher education, its advantages and disadvantages, and the analysis of undergraduate program curricula in cloud computing of American universities are provided below.

Cloud computing definitions. There are various definitions of cloud computing. In Wikipedia this term is defined as "the on-demand availability of computer system resources, especially data storage and computing power, without direct active management by the user" [4]. The similar definition is provided by Microsoft specialists, who define cloud computing as "the delivery of computing services - including servers, storage, databases, networking, software, analytics, and intelligence - over the Internet ("the cloud") to offer faster innovation, flexible resources, and economies of scale" [15].

A little bit different definition is given by Gartner group experts, who determine cloud computing as a style of computingin which scalable and resilient IT-enabled capabilities are provided as a service using Internet technologies [8].

The National Institute of Standards and Technology (NIST) had been working on finding the best definition of cloud computing for many years. In the final defin- 
ition of the term it is emphasized, that cloud computing is "a model for enabling convenient, on-demand network access to a shared pool of configurable computing resources that can be rapidly provisioned and released with minimal management effort or service provider interaction" [7].

As it can be seen from the definitions of cloud computing given above, there is no unified one. Different specialists consider it from their professional points of view, hence we can see cloud computing is defined as a style, model, service delivery etc. All the definitions have one feature in common: cloud computing deals with numerous innovation services and resources on the Internet with a possibility of easy access.

The popularity of cloud computing can be explained by its useful characteristics. NIST lists five essential characteristics of cloud computing: on-demand self-service, broad network access, resource pooling, rapid elasticity or expansion, and measured service [7].

DataFlair specialists give a broader list of main characteristics of cloud computing, which comprises ten points: resources pooling (provision of services to multiple customers using a multitenant model), on-demand self-service, easy maintenance, large network access, availability, automatic system, economical, security, pay as you go, measured service [6].

H.Jr. Katzan, Savannah State University, USA insists that a cloud computing service is to have the following operational characteristics: necessity, reliability, usability, and scalability. According to the author necessity refers to the idea that the advantage of users is depending on the service to meet their everyday needs. Reliability can be understood as the expectation that the service will be available when the user needs it. Usability means that the service is simple and convenient to use. Scalability refers to the fact that the service has corresponding capacity so that users can take advantage of the extensibility of the expandable service, which provides economies of scale [11].

Cloud computing is a well-known technology that is based on providing users with network access to various resources, for example, data or applications. Each cloud infrastructure is built on one of four service models. Let us consider these four service models.

SaaS (Software-as-a-Service). In this model, the service provider uses its own Internet application and provides consumers with the opportunity to use it through the World Wide Web. Key features of SaaS are the following ones:

- Users of the service do not pay for updates, installation, maintenance of the used hardware and software.

- Improving and updating the service is carried out transparently for users - they do not need to manually perform any manipulations for this.
- The provider charges a fee for using the service. The price is determined by the duration of access to the service (for example, per month) or the volume of operations performed.

PaaS (Platform-as-a-Service). TIn this model, the vendor offers customers to use their cloud infrastructure to install their software. The common platforms are OS, DBMS, as well as all kinds of development tools. Key features of PaaS are:

- Only a provider has access to managing PaaS cloud infrastructure. He also sets the set of available platforms, settings and services.

- The cost is determined by the volume of services provided, which can be measured by the time of their use, the number of operations, traffic and other factors.

laaS (Infrastructure-as-a-Service). Unlike the first two models, this model assumes greater freedom of action - the consumer can independently manage the services provided. These can be tools to manage and control a wide variety of resources.

DaaS (Desktop-as-a-Service). The DaaS model is a logical continuation of SaaS. Here, the service is not specific software, but a workplace that is ready to use and equipped with all the necessary tools. The 3data data center network uses this particular service model as the most modern and expandable [1].

Cloud computing in higher education. Cloud computing is widely used at education institutions of all levels (see Fig.1). The specific interest of our research is its applications in higher education. A. Masud, J. Yong, X. Huang [10] consider the following typical cloud computing applications for academics:

- the possibility of cloud computing usage as a personal workplace;

- it is useful for interactive teaching and learning, for social interactivity;

- the alternative of personalized learning environments to meet their personal needs and preferences;

- the ability for ubiquitous computing;

- the absence of necessity to save all the files on hard drives or flash drives;

- provision of huge capacity capabilities.

Corestack leading author outlines the following applications of cloud computing in higher education [9]:

- Virtual classrooms. Teachers can communicate face-to-face with students who can be located in any part of the world. This can expand the number and geography of students enrolled to the university.

- Solving the problem with textbooks. Electronic books and online videos can replace expensive or rare textbooks. This gives the possibility to have the access to materials free of charge or at low cost.

- Cloud-based applications and storage. Google Drive and Dropbox are used to store files. Therefore, software and hardware purchases become obsolete.

- Virtual labs. Online laboratories are safe, convenient and accessible anytime, anywhere and on any device. 
Undoubtedly, cloud computing has its advantages and disadvantages. I. Sagenmüller [2] considers the following advantages. Cloud computing improves institutional productivity and makes academic process more efficient due to the usage of combination of e-learning and b-learning and traditional courses. According to the author, cloud computing reduces expense, because a higher educational institution is to pay for the service in the case it uses it without any extra payments. The most significant positive aspect of cloud computing is its capability to improve collaboration due to easy access to any documents from any device at any time. The author has noted, that "cloud computing stores information in a large pool of servers around the world", hence there is no necessity to store information in one place. Moreover, the access to files has been improved and got easier. Cloud computing also helps financial and HR management, improves accountability.

In spite of numerous advantages, cloud computing has certain disadvantages: threat to confidentiality, lack of control, dependence of network performance. Corestack experts give a bit more different limitations of cloud computing at higher educational institutions concerning their management [9]. These are improper management because of insufficient personnel training or limited staff capabilities; security issues connected to numerous hacker attacks; necessity of regulation compliance with General Data Protection Regulation.

Having analysed the advantages and disadvantages of cloud computing, we should note it is an indispensable instrument in modern higher education.

Cloud computing in higher education has a rather long history. As a technology it has been adopted by numerous universities of the world. For instance, three universities in the US - Purdue University, Jacksonville State University and the University of Central Florida - use a cloud-based system called Libris for organising, collaborating and sharing visual resources. Cornell University uses a system called Red Cloud - a subscription-based service that provides access to virtual servers and storage on demand [5].

Curriculum Guidelines for Baccalaureate Degree Programs in Information Technology "Information Technology Curricula 2017" which overviews essential IT domains of competencies that all IT specialists should achieve can be adapted to specific needs of a particular higher education establishment when developing curricula in information technology, including cloud technologies. Guidelines describe essential domains, competences and subdomains in cloud computing [10]:

The scope covers the following items:

1. Cloud computing paradigm.

2. Cloud computing fundamentals, security principles, and applications.
3. Theoretical, technical, and commercial aspects of cloud computing.

4. Architecture and cloud software development.

5. Emerging technologies and existing cloudbased infrastructure.

Main competencies are determined in terms of ability to:

A. Analyze the meaning of cloud computing and understand the different cloud service categories. (Technologies).

B. Categorize cloud service types and be aware of privacy regulation impact on cloud application requirements. (Legal and Design).

C. Consider contract negotiations needed for cloud service delivery and develop the skills necessary to assess security breaches and their impact on the organization. (Risk Management).

D. Analyze when to use cloud applications and how architecture affects perfor-mance. (Technology).

E. Develop a cloud application with a user interface and understand data components. (Design).

The subdomains are presented in the following aspects: perspectives and impact, concepts and fundamentals, security and data considerations, using cloud computing applications, architecture, development in the cloud, cloud infrastructure and data.

It can be seen from the analysis of current curricula in information technologies, that higher education institutions around the world offer various programs for getting degrees in cloud computing as well, for example Bachelor of Science in Cloud Computing and Solutions (Purdue University, USA), Bachelor of Science in Cloud and Systems Administration (Western Governors University), Bachelor of Science in Cloud Technologies (Full Sail University, USA, Master in Cloud and Network Infrastructures (CNI) (EIT Digital Master School), Master in High-Performance and Cloud Computing (Northern (Arctic) Federal University, Russia), Master of Technology in Cloud Computing (K L University, India), Master in Security and Cloud Computing (SECCLO) (Joint Erasmus) (Kth Royal Institute Of Technology, Sweden).

As it has already been noted, the curriculum recommendations can be adapted to specific needs of a particular higher education establishment. The contents of curricula for bachelor's degrees in cloud computing have been studied on the example of three American universities: Full Sail University [8], Purdue University [3], and Western Governors University [13].

The analysis has shown that the structure of curricula in cloud computing at the US universities is similar. The curricula combine general science training and special training. General science training includes liberal arts and sciences, mathematical and natural sciences, wellness education. The study of general science disciplines occurs mainly in the first two years of study. 
Special disciplines cover:

- cloud technologies (cloud networking, cloud management platforms and services management, cloud applications and platform solutions, cloud deployment and operations, cloud architecture, cloud security and security testing for cloud applications);

- data (database systems, data storage systems, software-driven data centers, securing systems and data, migrating data and applications to the cloud);

- networking technologies (networking concepts, network administration, network security and security software);

- virtualization technologies (virtual computing, desktop virtualization, data center virtualization and cloud security).

To examine student knowledge and progress, modules (Career Module) and projects of different types (IT Capstone Written Project, Bachelor's Capstone in Cloud Computing and Solutions, Project and Portfolio) are conducted.

It is necessary to note that similar programs for getting bachelor's or master's degrees in Ukraine are absent.

Conclusions. Cloud computing is an excellent indicator of the rapid development of the modern education system. It enables students and administrators to get quickly an access to various applications and resources over the Internet at minimal cost. The use of cloud technologies affects the increase in efficiency and functionality due to the gradual elimination of costs associated with licenses, management, hardware and software. The flexibility of cloud computing frees up IT-staff from a large amount of maintenance, thus eliminating the high operational costs and the risks of disaster recovery and its cost. Cloud computing provides a versatile platform with simplified scalability. Therefore, it will be vital for higher education institutions. Thanks to cloud technologies, students have access to information and various technological services, especially advantages and opportunities, such as access to complex applications, minimal costs for cloud data storage, scalability and flexibility of an e-learning platform with cloud computing support. In this paper, we have presented a role analysis of cloud technology in higher education, as well as the analysis of specialty standards, with a focus on the curricula of several undergraduate degree programs in cloud computing of American universities.

\section{References:}

1. Что такое laaS, PaaS, SaaS и DaaS? URL: https://3data.ru/services/cloud/iaas-paas-saasdaas (Accessed: 30 Oct. 2019).
2. Advantages and Disadvantages of Cloud computing in higher education. URL: https://www.u-planner.com/en-us/blog/ advantages-and-disadvantages-of-cloudcomputing-in-higher-education

(Accessed: 30 Oct. 2019).

3. Bachelor of Science in Cloud Computing and Solutions < Purdue University Global. URL: https://azure.microsoft.com/en-us/overview/whatis-cloud-computing: https://catalog.purdueglobal. edu/undergraduate/business-informationtechnology/cloud-computing-solutions-bs/ (Accessed: 30 Oct. 2019).

4. Cloud computing. URL: https://en.wikipedia.org/ wiki/Cloud_computing (Accessed: 30 Oct. 2019).

5. Cloud Computing. URL: https://www.gartner. com/en/information-technology/glossary/cloudcomputing (Accessed: 30 Oct. 2019).

6. Features of Cloud Computing 10 Major Characteristics of Cloud Computing. URL: https://data-flair.training/blogs/features-of-cloudcomputing/ (Accessed: 30 Oct. 2019).

7. Final Version of NIST Cloud Computing Definition Published. URL: https://www.nist.gov/news-events/ news/2011/10/final-version-nist-cloud-computingdefinition-published (Accessed: 30 Oct. 2019).

8. Full Sail Catalog. URL: https://www.fullsail.edu/ resources/brochure-file/full-sail-catalog.pdf (Accessed: 30 Oct. 2019).

9. Higher Education Archives. URL: https://www.corestack.io/blog/tag/ higher-education/ (Accessed: 29 Oct. 2019).

10.Information Technology Curricula 2017. URL: https://www.acm.org/binaries/content/assets/ education/curricula-recommendations/it2017.pdf (Accessed: 29 Oct. 2019).

11. Katzan, Jr.H. (2019). ViewofTheEducation Value Of Cloud Computing. URL: https://clutejournals.com/ index.php/CIER/article/view/219/210 (Accessed: 30 Oct. 2019).

12.Masud, A., Yong, J. and Huang, X. (2012). Cloud Computing for Higher Education: A Roadmap. URL: https://www.researchgate.net/publication/ 234801620_(Accessed: 30 Oct. 2019).

13. Systems \& Cloud Administration Bachelor's Degree Program Online. URL: https://www.wgu.edu/ online-it-degrees/systems-cloud-administrationbachelors-program.html (Accessed: 29 Oct. 2019).

14. The Use of Cloud Technology in Higher EducationQS. URL: https://www.qs.com/cloud-technologyin-higher-education/ (Accessed: 29 Oct. 2019).

15.What Is Cloud Computing? A Beginner's Guide. URL: https://azure.microsoft.com/en-us/overview/ what-is-cloud-computing/(Accessed:30 Oct. 2019). 
Кулєшов С. О. Хмарні технології у вищій освіті США

У сучасному світі інфрормація набула значення одного з основних ресурсів. Наукові та навчальні, економічні та військові інститути в інформаційному суспільстві залежать від інфоормації та рівня розвитку комунікаційних технологій. Хмарні технології нині активно використовуються. Поняття хмарних обчислень має різні інтерпретації, але насамперед стосується технологій, що забезпечують потужні обчислювальні ресурси через Інтернет. Переваги впровадження иих систем найчастіше обговорюються стосовно бізнесу, але їх вплив на сектор освіти не менш суттєвий. Освітні заклади у всьому світі вже впровадили хмару у свій навчальний процес і використовують її величезний потенціал для інновацій. Хмарні сервіси - відмінна альтернатива традиційній освіті, оскільки вони не потребують великого дефріциту ресурсів для функціонування та великих витрат на комп'ютери та інші пристрої. Для успішного впровадження і використання хмарних сервісів постійно вимагається велика кількість кваліфрікованих спеціалістів. Результати огляду літератури показують, що США є одним із лідерів на ринку інформаційних послуг, а американські університети займають провідні позиції у світових рейтингах за якістю IT-освіти. Сучасні американські освітні установи постійно звертаються до використання хмарних сервісів $і$ вже мають величезний досвід використання хмарних обчислень. Слід зазначити, що вітчизняні заклади вищої освіти не так активно інтегрують хмарні технології в навчальний процес порівняно з американськими колегами. 3 високим скороченням бюджету на вищу освіту в українських університетах і постійно зростаючим попитом на послуги інфоормаційних технологій українські заклади вищої освіти повинні розглянути можливість прийняття стратегій із використання хмарних обчислень для задоволення попиту на IT-послуги. За умов скорочення державного фрінансування українських закладів вищої освіти та поступового їх переведення на самодостатне економічне існування хмарні обчислення можуть запропонувати вигідні бізнес-моделі для українських університетів, оскільки в останніх часто не вистачає ресурсів і знань для управління необхідною інфрормаційно-технологічною підтримкою освітньої, науково-дослідної та дослідницької діяльності, яка повинна забезпечуватися у сучасній вищій освіті, тоді як хмарні обчислення мають на меті усунути ці складнощі.

Ключові слова: хмарні обчислення, бакалавр наук, навчальний план, вища освіта, освітні технології. 